\title{
Por que estudar a história indígena?
}

Why study Indigenous History?

Jorge Victor de Araújo Souza*

\section{Wittmann, Luisa Tombini (Org.) \\ Ensino (d)e História Indígena}

Belo Horizonte: Autêntica, 2015. 202p.

A implementação da Lei 11.645/08 tornou obrigatório o ensino de história e cultura indígena, assim como o da afro-brasileira. No entanto, ainda há descompasso entre as necessidades da realidade escolar e a licenciatura de história nas universidades brasileiras no que se refere a essas áreas, pois nem sempre foram oferecidas disciplinas basilares aos jovens universitários. Publicações como a organizada pela historiadora Luisa Tombini Wittmann ajudam a sanar possíveis faltas, além de serem importantes dispositivos para o auxílio na formação continuada de nossos professores.

A intenção principal da obra é fornecer subsídios sobre história indígena aos professores da educação básica. Para tal, a organizadora reuniu resultados de recentes pesquisas que cobrem do século XVI ao XX, do Norte ao Sul do país. Essa amplitude, à primeira vista, parece fragilizar o tratamento da temática. Entretanto, ao fim da leitura percebe-se por dois motivos que esse é um dos aspectos mais positivos da publicação. Primeiro, porque os capítulos foram escritos por especialistas em história indígena. Segundo, porque a organizadora foi habilidosa em alinhavar distintas abordagens sobre um mesmo tema, mantendo assim a proposta geral do livro.

Na introdução, Luisa Tombini faz rápido balanço historiográfico sobre o tema e salienta que a obra está alinhada à "Nova história indígena", em que "o que importa é compreender o indígena como sujeito histórico que age conforme sua leitura do mundo, baseada tanto em códigos socioculturais quanto nas

\footnotetext{
* Doutor em História pela Universidade Federal Fluminense (UFF). Professor de História da América Colonial na Universidade Federal do Rio de Janeiro (UFRJ). Docente do Programa de Pós-Graduação em Ensino de História (UFRJ), Programa de Pós-Graduação em História Comparada (PPGHC). Rio de Janeiro, RJ, Brasil. jvictoraraujos@gmail.com
} 
experiências desencadeadas pelo contato. Para isso, necessitamos aproximar a História da Antropologia, ofício cujo cerne é interpretar a alteridade" (p.17). Não à toa, o livro é dedicado a John Monteiro, historiador que muito contribuiu para novas abordagens sobre história indígena no Brasil, incluindo a até então pouco conhecida escravidão dos índios. Tombini chama a atenção para o uso de documentos históricos produzidos por não índios. Acarretaria isso apenas uma história que privilegia certas visões sobre os indígenas? Para responder a tal questão, a autora salienta que a "Nova história indígena" é muito cuidadosa com aquilo que deveria ser o leitmotiv de uma investigação em arquivos, qual seja, a análise minuciosa da documentação: "nas fontes produzidas por brancos se encontram vestígios que permitem seguir alguns dos caminhos traçados pelo outro: pistas que reconstroem histórias indígenas" (p.19). Nos cinco capítulos que compõem a obra os autores expõem os resultados de pesquisas e reflexões que levaram em conta a leitura da documentação "a contrapelo", e que dessa forma acabam por destacar senão um protagonismo indígena na história do Brasil, pelo menos a presença de índios como sujeitos atuantes.

No primeiro capítulo, "Ensino de história indígena", Giovani José da Silva, logo de início, faz uma provocação a respeito de nossa memória escolar: o que recordamos a respeito do índio no que nos foi ensinado? De acordo com o autor, muitas respostas se limitariam às comemorações do mês de abril, quando todos os estereótipos sobre a cultura indígena são encenados em sala de aula. Além disso, o autor lembra que no senso comum os índios estão relegados a um determinado passado colonial. Depois de expor esse quadro desanimador, são fornecidas informações que ajudam a desfazer imagens errôneas a respeito das nações indígenas; uma delas, por exemplo, versa sobre o suposto "mito do desaparecimento dos índios". Giovani Silva também discute o uso recorrente do conceito de "aculturação" no que se refere ao longo processo de contato dos índios com povos não índios. A ideia de que grupos deixariam de ser indígenas por se apropriarem de produtos comercializados globalmente serve de pretexto aos que querem extinguir os povos originais no intuito de se apossarem de suas terras.

O ponto alto do primeiro artigo é o relato que o autor faz de suas experiências como professor de História entre os Kadiwéu entre 1997 e 2004. Giovani Silva descreve o desafio linguístico que enfrentou e as diferentes concepções de história, pois existem "histórias de admirar" que não necessitam de comprovação de veracidade para serem eficazes na comunidade. Além disso, alguns eventos são vistos pelos Kadiwéu sem amarras temporais, como a 
Guerra do Paraguai, que para os mais velhos estaria ainda em curso. $\mathrm{O}$ artigo termina enfatizando como os indígenas são nossos contemporâneos, indo assim de encontro à ideia - infelizmente arraigada na sociedade brasileira - de "congelamento temporal" dos povos originais.

No segundo artigo, Almir Diniz de Carvalho Júnior escreve sobre "índios cristãos na Amazônia colonial". O historiador começa seu texto tecendo uma crítica a certa imagem da Amazônia como região vazia, pronta para a exploração de europeus. O artigo objetiva produzir uma reflexão sobre as formas de inserção dos índios às lógicas coloniais, sobretudo partindo das práticas das missões religiosas. A missão é aqui tratada como espaço de controle e de sociabilidades, e é nesse sentido que o autor ressalta os ofícios exercidos pelos indígenas como um locus marcador das mudanças pós-conversão; é o caso dos "práticos", tão necessários em área onde a navegação era o principal meio de transporte. Ao lançar olhar sobre as relações estabelecidas entre indígenas e europeus, Almir Diniz ressalta algo necessário de ser apresentado em sala de aula: uma região amazônica complexa e rica no que diz respeito a sua formação.

Maria Albuquerque Dantas é a responsável pelo terceiro capítulo do livro, "Identidades indígenas no Nordeste". Ao iniciar, a historiadora faz questão de questionar o senso comum, apresentando dados recentes do IBGE que apontam o crescimento da população indígena. Isso coloca também em xeque muitas interpretações acadêmicas da década de 1970 que apostavam no desaparecimento dos índios ao longo dos anos. A autora parte do estudo de Pernambuco para discutir a relação entre formação das identidades e as lutas pelo direito à terra. Para tal, tece um panorama sobre as transformações ocorridas após a extinção de aldeias na região entre os séculos XVIII e XIX. O ponto alto do artigo é a apresentação das diversas estratégias acionadas pelos indígenas ao verem seus territórios sob ameaça, e o quanto tais mecanismos de reivindicação passam quase sempre pela construção e reconstrução de suas identidades. Nesse sentido, a autora destaca os ataques perpetrados pelas autoridades do Estado ao ritual Ouricuri dos Carijó, na tentativa de desmantelar importante expressão da coletividade dos índios. Seu artigo traz dados substantivos para reflexão sobre a historicidade das lutas indígenas.

No quarto capítulo, Luisa Tombini Wittmann analisa as "relações interétnicas ao sul". Interessante notar que no senso comum, sempre ele, costuma prevalecer a ideia de que os índios são restritos ao território amazônico. Portanto, em uma sala de aula, é de suma importância reflexões como as trazidas 
por Wittmann sobre a ocupação de terras indígenas por imigrantes europeus e as resistências tecidas pelos índios na região sul do país. Ao final do século XIX, a arcaica retórica "barbárie versus civilização" foi acionada por governantes provinciais para classificar respectivamente índios e imigrantes germânicos. Na tomada das terras indígenas, Wittmann destaca a ação dos "bugreiros" "quem mais conhecia o modo de vida dos índios tinha como profissão matá-los" -, afirma (p.120). Wittmann faz uso de fontes variadas, inclusive orais, e é dessa forma que consegue tecer a história de sobreviventes de genocídios empreendidos por bugreiros. É caso da menina índia Ana, que foi entregue a uma família de imigrantes. Tais sobreviventes, com grande trauma, viveram entre mundos que se chocavam. Uma das principais lições que podem ser usadas na escola é sobre a diversidade presente na formação de uma população que por muitas vezes se ufana de "seu passado europeu".

O último capítulo, que versa sobre "movimento indígena no Brasil", é assinado por Clovis Antonio Brighenti. Lançando mão de uma revolta Guarani conhecida como "desbatismo", Brighenti nos lembra que resistência indígena não é fenômeno contemporâneo, contestando assim a ideia comum de que os índios foram passivos durante o processo de colonização. O historiador estabelece como ponto de partida eventos bem recentes, frutos de anos de lutas dos povos originais por seus direitos, como o ato dos Guarani Kaiowá no aterro do Flamengo, no ano de 2012. Logo depois, é traçado um painel sobre a historicidade da legislação indigenista. O que importa, salienta, é que tais políticas não foram benesses concedidas por governos sucessivos, mas sim, resultado de lutas históricas. $\mathrm{O}$ artigo em questão encerra muito bem o livro, pois apresenta os índios como atores políticos que ainda lutam no cenário nacional.

Os artigos não são propositivos no que se refere ao uso de suas informações em sala de aula. A solução encontrada foi anexar sugestões de atividades com as mais variadas documentações, ao final de cada um, e materiais comentados sobre a temática indígena ao final do livro. Hoje, os índios passam ainda por massacres, por retiradas de seus direitos e pela degradação de sua imagem por variados canais midiáticos que buscam reforçar ideias preconceituosas presentes na opinião pública. Não obstante, ainda lutam bravamente, resistindo àqueles que querem lucrar com todas as formas de seu extermínio. Também por isso, a leitura de Ensino (d)e História Indígena faz-se urgente.

Resenha recebida em 31 de maio de 2017. Aprovada em 17 de julho de 2017. 